\title{
Book Review: Paulo Coelho's The Spy
}

Author: Paulo Coelho

Translated from: Portuguese

Translated by: Zoe Perry

Published: 2016

Publisher: Vintag, Penguin Books.

Book Length: 186 pages.

Price: Rs. 299 (Indian Currency)

Reviewed by

Sayantan Pal Chowdhury

Assistant Teacher, Siliguri Baradakanta Vidyapith (HS).

Email:noisayantan@rediffmail.com

Paulo Coelho's latest book The Spy, published in 2016, has been translated from the Portuguese by Zoe Perry. It deals with the encounter of the historical figure Margaretha Gertrude Zelle, famously known as Mata Hari. The incident took place during the World War I. As the epilogue of the book contains the report published in the newspaper on October 15, 1917 about her encounter, it was clearly reported that she had been "court-martialled on the charge of espionage." In this story Coelho has used the history and presented it wrapped in the colourful cover of myth and fantasy. He has used imaginary and most probable conversations.

If we take a bird's eye view of the story, we can divide it into a complete form of beginning-middle-end structure. The beginning of the story contains the 'Prologue' where the morning of the encounter is retold with a very detailed appearance of Mata Hari, her physical appearance, her mental stability, her death sentence. In the 'middle' the narrator, Mata Hari, in the first person gives a minute description of her adventurous life, her experiencing life, her understanding of human dignity. In the 'end' we cannot hear the narrator's voice anymore; rather, it is replaced by the voice of her lawyer, Maitre Clunet. The most of the story is in the form of letters - the first one from Mata Hari, and the second one from Clunet. In Parts I and II Mata Hari writes to Clunet the letter which she wants to be delivered to her daughter, Non. In Part III the letter is written by Clunet to Mata Hari which is delivered to her on the eve of her encounter.

The encounter of Mata Hari was a wrong decision and the power-play of the war politics. She could not be "incriminated" as no such evidence was found against her. She was caught without much of her knowledge on a morning from room 131 of the Hotel Elysee Palace where she was found "in a silk robe, still taking her breakfast." (Coelho, 161) The only thing she knew was that she was innocent. When she came to know all about what was played behind her, she became stoic. She willingly handed herself over her fate. Her encounter has been very minutely and passionately described by the author in the Prologue- "Then her knees buckled and her body fell to the right, legs doubled up beneath the fur coat. And there she lay, motionless, with her face turned toward the heavens." (Coelho 7)

(c) AesthetixMS 2016. This Open Access article is published under a Creative Commons Attribution Non-Commercial 4.0 International License (http://creativecommons.org/licenses/by-nc/4.o/), which permits non-commercial re-use, distribution, and reproduction in any medium, provided the original work is properly cited. For citation use the DOI. For commercial re-use, please contact editor@rupkatha.com. 
It is the expertise and the intelligence of the author that he plays with fact and fancy. He makes the readers knowledgeable about the history which must make human dignity ashamed. Mata Hari could not get the chance to prove her innocence. Her submission to the hands of face and the injustice done to her was not helpless; rather, she stands upright even to the very end. She faces the world which was against an independent woman. Feminine aspects are very prominent. At the end of the story we come to know that another woman, Helene Brion, was one of her cell mates. She fought for the "women's rights," that "women have the same rights as men." (Coelho 171)

As the cover page tells us, "Her only crime was to be an independent woman," Mata Hari's case was an evidential case of feminine fights for equal rights. In a world of male domination she wandered one place to another in search of her identity and in so doing she had to choose to sell her beauty. She broke the social myth that sex should follow love. Soon she understood that sex is mechanical- "I began to associate sex with something mechanical, something that had nothing to do with love." (Coelho 21) She was raped by the principal when she was in her teenage. She tried to hide the incident from others from a fear of being expelled. Not only she but many other girls of her age suppressed the same experience. She got married to a Dutch soldier Rudolf, but the marriage did not give her peace. He had always been suffering in those days from revealing her wife to others and from a fear to lose her. Hari was treated as an object. As soon as the incident of Andreas' wife's suicide was committed, Mata Hari had to leave her husband and her only daughter. In different places she had to lead her life and so, Hari started to share bed with dominant male characters, sometimes with the army people, sometimes with the artists. She was conscious about her beauty and so she knew how to use it to earn her bread and luxury. Whatever came in her life, she experienced everything. Striptease became a myth as Barthes told. It is a collection of images of some physical acts, some postures.

While she was began travelling from one place to another becoming an object in the hands of male characters, in take Holland into account, "The drums of war were not yet beating, and entering the country was still easy." (Coelho 42) She met many influential men indifferent countries and all of them had the lust to get her in their beds. She used those men as being a woman, alone in the world, with no one to look after, she needed money and support. She got money, sometimes more than what she had needed, but there was always a question mark whether she got support. The author gives a proper mapping of geographical locations following which Mata Hari travelled.

Another thing that is notable in the story is the cultural difference. Mata Hari's presentation of the tribal dance form of the East shows how the colonial West was attracted by the colonized East. According to Mata Hari's husband, "no Eauropean woman could compete with an Asian woman." (Coelho 25) And there are other references also like, “...and he told me this kind of ballet came from an ancient Indian tradition that combined yoga and meditation." (Coelho 31) But what Mata Hari presented before her viewers was not an form of "oriental dance." What Madame Guimet arrested was the cheating done by Hari, the act of cheating of the Orientals by the Occidentals. The West's adoption of the East can be noted here.

To conclude, Coelho has presented the sufferings of Mata Hari as an answer to the prediction of Clunet, when he writes in his letter, "Perhaps one day history might also do justice to you, though I doubt it." (Coelho 173) Clunet's doubt has been wiped out when Coelho takes this subject from history to reveal the life of a woman who fought for her independent life at a time when society was not a very open a place for women. This book sympathizes with Mata Hari for her being one of the first women who became a martyr for equal rights, who had to accept death 
becoming a victim of suspicion. While reading the story the reader must be crowded with the ideas of feminine rights, geographical locations, war politics and human dignity. Coelho's use of myths is another attractive feature of him. The reference to the Greek myth about Psych and Eros has been used again in this book after its use in his another famous book Adultery. The use of time from present to past and again to present with a hope for future when history should do justice to her is notable. As in all his books Coelho has again proved the importance of Love. Sex is no sin; rather, everything and every moment in life are important. Except this, what remains, is human dignity.

\section{Reference:}

Coleho, Paulo (2016). The Spy. Haryana: Penguin Books.

Sayantan Pal Chowdhury is an Asst. Teacher with Siliguri Baradakanta Vidyapith (HS) and writer. He has completed M.A. in English and again in Linguistics. He has published many papers in national and international journals. He has attended many national and international conferences and seminars. His debut short story 'Progress' has been published in New Asian Writing Short Story Anthology 2013. 